\title{
STRATEGI BISNIS PENGOLAHAN IKAN PADA UD SBY CORPORATION DI DESA WANGUNDADI, KECAMATAN DUDUK SAMPEYAN KABUPATEN GRESIK
}

\author{
*Suyoto, Dona Wahyuningsih Laily, Farid Wajdi, Edy Budio Santoso, Fadik Mushonnief Eka \\ Putra
}

*Fakultas Perikanan Universitas Islam Lamongan

Jl. Veteran no. 53A Lamongan Phone/Fax. 0322_324706

\begin{abstract}
ABSTRAK
Faktor eksternal yang menjadi ancaman pada pengolahan ikan di UD SBY Corporation antara lain Barrier to entry usaha pengolahan ikan rendah, persaingan dengan perusahaan sejenis, persaingan dengan produk substitusi dan ingkat inflasi yang cenderung meningkat. Berdasarkan analisis lingkungan internal perusahaan didapatkan kekuatan perusahaan antara lain lokasi perusahaan strategi, memiliki prestasi dan penghargaan, perusahaan telah menjalankan kegiatan produksi berdasarkan HACCP, sedangkan kelemahan perusahaan antara lain pemilik tidak hanya fokus menjalankan pada satu usaha yaitu usaha pengolahan ikan, segala keputusan kegiatan usaha masih bergantung pada pemilik perusahaan, tidak adanya divisi pemasaran secara khusus, pesamaran dilakukan oleh pemilik, Administrasi dan keuangan perusahaan belum rapi, modal usaha terbatas, dan ketidakmampuan perusahaan mendapatkan bahan baku ikan.
\end{abstract}

Kata Kunci: Strategi Bisnis, SWOT, Pengolahan Ikan

\section{PENDAHULUAN}

Ikan merupakan salah satu sumber protein dan memiliki komposisi asam amino yang lengkap, juga diketahui mengandung lemak yang kaya akan asam lemak tak jenuh jamak atau polyunsaturated fatty acids (PUFA) yang berkhasiat bagi kesehatan. Asam lemak tak jenuh jamak yang banyak terdapat pada ikan adalah asam lemak omega 3, terutama eikosapentanoat/ EPA dan asam dokosaheksanoat/ DHA (Irianto, 1993 dalam Irianto dan Soesilo, 2007).

Melihat potensi ikan Indonesia dan manfaat yang dihasilkan oleh ikan seharusnya tingkat konsumsi ikan per kapita Indonesia sebanding atau bahkan lebih tinggi daripada negara-negara Asia lainnya. Tingkat konsumsi Indonesia mengalami peningkatan setiap tahunnya dan hingga 2010 tingkat konsumsi ikan Indonesia mencapai 30,47 kg/kapita/tahun. Negaranegara Asia lainnya pada tahun yang sama lebih unggul jika dibandingkan Indonesia seperti Jepang, Korea Selatan, Malaysia, Singapura, Filipina, dan Hongkong dengan tingkat konsumsi secara berturut-turut sebesar 110, 85, 54, 70, 40, dan 80 $\mathrm{kg} / \mathrm{kapita} / \mathrm{tahun}$.

Menurut Widiarti dkk., (2010), salah satu penyebab rendahnya tingkat konsumsi ikan Indonesia karena alasan tingkat kepraktisan ketika mengonsumsi ikan. Mengonsumsi ikan dinilai repot dan memerlukan alokasi waktu khusus, karena mengonsumsi ikan utuh harus dikerjakan secara spesial dan tidak dapat dilakukan sambil menyelesaikan pekerjaan lainnya.
Melihat hal tersebut, peningkatan ketersediaan produk olahan berbasis ikan yang beragam menjadi kebutuhan yang diutamakan. Adanya pengembangan produk ikan diharapkan mampu memberikan nilai tambah pada ikan dan memberikan variasi produk sehingga produk olahan ikan tersebut dinilai tidak merepotkan lagi dan dapat menjangkau pasar yang lebih luas.

Terjadinya perubahan dalam lingkungan eksternal perusahaan dan kecepatan mendapatkan bahan baku pada musim paceklik, mengharuskan perusahaan membuat strategi yang tepat, terutama strategi dalam pengadaan bahan baku ikan sehingga kegiatan produksi tidak terganggu. Adanya strategi yang tepat untuk saat ini ataupun untuk beberapa tahun ke depan membuat perusahaan lebih siap dalam menghadapi perubahan yang terjadi di lingkungan eksternal dengan melihat pula pada lingkungan internal yang perusahaan miliki.

\section{METODE PENELITIAN}

\section{Tempat dan waktu}

Penelitian ini di laksanakan di Perusahaan Pengolah Ikan UD SBY Corporation, Desa Wangundadi, Kecamatan Duduk Sampeyan, Kabupaten Gresik. Kegiatan ini di laksanakan pada bulan Februari - Maret 2017.

\section{Metode Penelitian}

Metode yang digunakan dalam penelitian ini adalah metode pengumpulan 
data yang dilakukan dengan teknik pengamatan langsung (observasi), melakukan wawancara secara mendalam (indepth). Metode pengumpulan data lainnya yaitu dengan studi pustaka yaitu dengan mencari sumber lain yang dapat dijadikan acuan terkait penulisan.

\section{Metode Pengolahan dan Analisis Data}

Data yang diperoleh diolah secara deskriptif kualitatif. Analisis deskriptif kualitatif untuk menentukan faktor yang menjadi kekuatan, kelemahan, peluang serta ancaman perusahaan, analisis SWOT, kemudian alternatif strategi yang didapatkan dipetakan ke dalam arsitektur strategik.

\section{Matrik SWOT}

Ada delapan langkah yang terlibat dalam pembuatan matriks SWOT, yaitu 1) mengidentifikasi faktor-faktor kunci yang menjadi kekuatan perusahaan, 2) mengidentifikasi faktor-faktor kunci yang menjadi kelemahan perusahaan, 3) mengidentifikasi faktor-faktor kunci yang menjadi peluang bagi perusahaan, 4) mengidentifikasi faktor-faktor kunci yang menjadi ancaman bagi perusahaan, 5) membuat strategi SO, 6) membuat strategi ST, 7) membuat strategi WO, dan 8) membuat strategi WT. Matriks SWOT dapat dilihat pada Tabel 1.

Tabel 1. Matrik SWOT

\begin{tabular}{lcl}
\hline & $\begin{array}{c}\text { Kekuatan } \\
\text { (Strengths) }\end{array}$ & $\begin{array}{c}\text { Kelemahan } \\
\text { (Weaknesses) }\end{array}$ \\
\hline $\begin{array}{l}\text { Peluang } \\
\text { (Opportunities) }\end{array}$ & Strategi SO & Strategi WO \\
$\begin{array}{ll}\text { Ancaman } \\
\text { (Threats) }\end{array}$ & Strategi ST & Strategi WT \\
\hline
\end{tabular}

Sumber: David (2009).

\section{Perancangan Arsitektur Strategik}

Langkah yang dilakukan adalah memperjelas visi, misi, dan tujuan perusahaan yang dimiliki, menganalisis lingkungan eksternal dan internal perusahaan. Hasil identifikasi lingkungan eksternal adalah peluang dan ancaman, sedangkan identifikasi lingkungan internal adalah kekuatan dan kelemahan. Hasil identifikasi tersebut merupakan input untuk memformulasikan strategi pada matriks SWOT. Hasil matriks SWOT berupa strategi-strategi SO, WO, ST, dan WT. Hasil strategi pada matriks SWOT dijabarkan dalam bentuk program-program untuk mencapai sasaran. Selanjutnya mengidentifikasi tantangan yang akan dihadapi perusahaan. Tantangan merupakan cara-cara yang dilakukan perusahaan untuk memperoleh keunggulan bersaing yang baru.

\section{HASIL DAN PEMBAHASAN}

\section{Gambaran Umum UD. SBY Corporation}

UD SBY Corporation merupakan industri rumah tangga dengan skala besar yang bergerak di bidang pengolahan ikan dengan bahan baku ikan laut yaitu ikan pelagis seperti tuna, marlin dan kakap. Produk yang dihasilkan yaitu bakso ikan yang merupakan produk unggulan, dan olahan lainnya seperti nugget ikan, kaki naga, siomay, ekado.

Produk-produk dari UD SBY Corporation ini telah didaftarkan di DEPDAG tahun 2008 dan sekarang dalam proses pendaftaran sertifikasi Halal dari MUI Jawa Timur.

\section{Lokasi dan Keadaan UD. SBY Corporation}

Industri ini menempati lokasi dengan luas tanah $3500 \mathrm{~m}^{2}$, namun yang digunakan sebagai pabrik pengolahan ikan hanya seluas $400 \mathrm{~m}^{2}$ yang terdiri dari ruang penggilingan daging, ruang pengadaan bahan baku, ruang pencucian, ruang perebusan, ruang pendinginan, ruang pengolahan, ruang pengepakan dan ruangan penyimpanan produk yang berada dekat dengan ruang administrasi. Sebagian lagi lahan digunakan untuk tempat tinggal karyawan. Tempat ini dipilih karena lokasinya strategis sehingga memudahkan dalam pemasaran dan pembelian bahan produksi, serta dekat dengan jalan utama untuk memudahkan pemasok dalam pengiriman bahan baku.

\section{Visi, Misi dan Tujuan UD SBY Corporation}

Visi UD SBY Corporation adalah menjadi perusahaan pengolahan ikan terbaik di Jawa Timur khususnya di Kabupaten Gresik dengan produk yang dapat diterima masyarakat. Misinya menghasilkan produk yang berkualitas, memasarkan produk olahan ikan ke masyarakat luas sebagai produk yang sehat dan bergizi dengan harga terjangkau dan memberikan pelayanan yang baik kepada konsumen. Tujuannya adalah membantu untuk peningkatan konsumsi ikan nasional melalui produk olahan ikan dan menciptakan lapangan pekerjaan untuk masyarakat sekitar.

\section{Sumberdaya UD SBY Corporation Sumberdaya Manusia}

UD SBY Corporation memiliki tenaga kerja tetap yakni sebanyak 17 orang. Status pendidikan tenaga kerja merata, untuk kepala bagian di pegang oleh lulusan sarjana 
dengan berbagai jurusan. Direktur yang sekaligus pemilik memiliki latar belakang S1 Fakultas Perikanan, kepala bagian administrasi dan keuangan merupakan lulusan S1 Teknik Industri, kepala bagian produksi dan operasional merupakan lulusan S1 Perikanan, sedangkan karyawan dari lulusan SD, SMP dan SMA.

\section{Sumberdaya Fisik}

Adapun rincian sumberdaya fisik perusahaan dapat dilihat pada Tabel 2 .

Tabel 2. Rincian Sumberdaya Fisik UD SBY Corporation

\begin{tabular}{clc}
\hline No. & \multicolumn{1}{c}{ Jenis } & Jumlah \\
\hline 1. & $\begin{array}{l}\text { Bangunan (kantong dan } \\
\text { pabrik) }\end{array}$ & 1 \\
\hline 2. & Peralatan Produksi & \\
\hline & Mesin Chopper & 1 \\
& Silent Cutter & 1 \\
& Kompor satu set & 12 \\
& Mesin cetak bakso & 1 \\
& Freezer & 7 \\
& Cold Storage & 1 \\
\hline 3. & Peralatan Kantor & 1 \\
\hline & Laptop & 1 \\
& Printer & 4 \\
& Meja & 5 \\
\hline Kursi & 1 \\
\hline F. & Fasilitas Komunikasi \\
\hline Telepon & Sarana Transportasi \\
\hline & Mobil pick up & 2 \\
Motor &
\end{tabular}

Sumber: UD SBY Corporation (2016)

\section{Sumberdaya Modal}

Modal usaha UD SBY Corporation berasal dari modal pribadi pemilik yaitu ibu Purwasih, sehingga ketika ingin melakukan pengembangan usaha terkendala oleh modal. Hingga saat ini perusahaan tidak menggunakan pinjaman ataupun melakukan kerjasama dengan penanaman investasi.

\section{Analisis Lingkungan Perusahaan Analisis Lingkungan Eksternal}

a. Kekuatan Ekonomi

Pada saat penelitian dilaksanakan tahun 2017 tingkat inflasi yaitu 3,60\%, sedangkan bulan sebelumnya adalah 4,45\%. Dampak inflasi yang paling dirasakan yaitu ketika terjadi kenaiakan bahan-bahan produksi seperti terigu dan telur. Ketika harga bahanbahan tersebut meningkat maka biaya produksi perusahaan akan meningkat pula. Hal tersebut menjadikan perusahaan yang saat ini sedang mengalami penurunan penjualan, mengalami penurunan keuntungan juga akibat perusahaan tidak dapat meningkatkan harga produk.

b. Kekuatan Sosial, Budaya, Demografi dan Lingkungan

Saat ini perubahan gaya hidup yang serba ingin cepat, praktis dan sesuai selera serta semakin banyaknya perubahan gaya hidup sehat membuat perusahaan berlombalomba untuk membuat produk yang diinginkan masyarakat. Seiring dengan peningkatan kesejahteraan, masyarakat semakin memahami pentingnya kesehatan. Salah satu makanan yang menyehatkan yaitu ikan yang kini mulai disebarluaskan sehingga masyarakat mulai menyukai ikan. Hal ini terlihat dari pengeluaran konsumsi ikan yang semakin meningkat dari tahun 2013 hingga 2016. Pengeluaran rata-rata konsumsi ikan per kapita dapat terlihat pada Tabel 3.

Tabel 3. Pengeluaran Rata-rata Konsumsi Ikan Nasional Tahun 2013 - 2016

\begin{tabular}{cc}
\hline Tahun & Jumlah $(\mathrm{Rp})$ \\
\hline 2013 & 15.984 \\
2014 & 16.987 \\
2015 & 18.945 \\
2016 & 19.648 \\
\hline
\end{tabular}

Sumber : Badan Pusat Statistik (2009)

Peningkatan rata-rata konsumsi ikan dapat diindikasi karena adanya peningkatan jumlah penduduk Indonesia. Peningkatan tersebut dapat dijadikan aspek penting terkait kesempatan untuk memasarkan produk olahan.

c. Kekuatan Politik, Pemerintah dan Hukum

Pemerintah dengan beberapa pihak bekerjasama terkait penjaminan kredit atau pembiayaan kepada UMKM dan Koperasi yaitu antara Menteri Pertanian, Menteri Keuangan, Menteri Kehutanan, Menteri Kelautan dan Perikanan dan Perbankan. Program KUR juga di dukung oleh Kementerian BUMN, Kementrian Bidang Perekonomian dan Bank Indonesia.

Tidak hanya bantuan berupa material, namun bantuan juga bisa berupa non material yang dibutuhkan perusahaan. UD SBY Corporatin tercatat pernah mendapatkan bantuan non material berupa peralatan karena perusahaan sering mendapatkan juara ketika melaksanakan perlombaan. Adanya bantuan dari pemerintah tersebut tentunya dapat dijadikan sebagai peluang perusahaan agar usaha tersebut tidak terkendala lagi dengan modal. 


\section{d. Kekuatan Teknologi}

Teknologi yang digunakan perusahaan UD SBY Corporation yaitu teknologi di bidang produksi. Perusahaan menggunakan mesin penghancur daging ikan (chopper) dan mesin pengadon (silent cutter) serta mesin cetak bakso yang mempermudah kegiatan produksi. Selain itu perusahaan juga menggunakan freezer untuk menyimpan hasil olahan yang telah dikemas. Peralatan produksi yang dimiliki oleh UD SBY Corporation ini tergolong masih tertinggal dengan pesaing utama yang telah memiliki peralatan lebih canggih yaitu pada alat perebusan.

Teknologi komunikasi untuk mendapatkan informasi seperti telepon dan handphone juga digunakan perusahaan dalam melakukan hubungan dengan agen ataupun pemasok, sehingga mempermudah komunikasi dengan pihak-pihak yang berhubungan dengan perusahaan. Adanya perkembangan teknologi tersebut dapat dijadikan suatu peluang untuk memperlancar usaha.

\section{Analisis Lingkungan Industri}

1. Ancaman Masuknya Pendatang Baru a. Skala Ekonomi

Perusahaan pengolahan ikan seperti UD SBY Corporation yaitu pembuatan bakso ikan, siomay dan sebagainya dapat dilakukan oleh siapa saja mulai dari skala usaha rumah tangga hingga besar. Hal ini tergantung pada kemampuan setiap perusahaan melakukan produksi dan kapasitas produksi, sehingga perusahaan baru dapat dengan mudah masuk ke dalam industri untuk bersaing dengan perusahaan.

b. Diferensi Produk

Produk olahan ikan UD SBY Corporation sama dengan produk olahan yang diproduksi oleh perusahaan lainnya, tidak ada perbedaan yang signifikan terhadap produk tersebut. Perbedaan terlihat hanya pada kualitas produk, sehingga perusahaan baru akan mudah masuk dan bersaing karena produk UD SBY Corporation tidak memiliki suatu keunikan terhadap produk yang lain.

c. Kebutuhan Modal

Usaha pengolahan ikan dalam skala besar tentunya harus memiliki modal yang besar pula karena jumlah produksi yang besar mengharuskan perusahaan melakukan pengadaan peralatan yang harganya berkisar jutaan. Selain itu untuk masalah permodalan, perusahaan dapat mengajukan peminjaman modal karena adanya bantuan untuk UMKM. Dapat disimpulkan bahwa kebutuhan modal dalam menjalankan usaha bukan merupakan suatu hambatan besar.

\section{d. Biaya Beralih Pemasok}

Kebutuhan akan bahan baku dapat terpenuhi dari berbagai pemasok yang ada. Jumlah pemasok ikan cukup banyak tersebar di beberapa daerah di Indonesia sehingga biaya beralih pemasok cukup rendah.

\section{Persaingan antar Perusahaan dalam Industri}

Persaingan perusahaan dalam industri merupakan hal yang biasa terjadi. Hal tersebut terjadi karena perusahaan samasama ingin mendapatkan keuntungan dengan peluang usaha yang ada. Di Kabupaten Lamongan sendiri, terdapat empat perusahaan yang sejenis dengan UD SBY Corporation dan memiliki tujuan pasar yang sama yaitu wilayah Jombang, Gresik dan Surabaya. Jika dibandingkan, beberapa perusahaan pesaingnya unggul dalam hal kualitas dan inovasi sehingga mendapatkan penghargaan dan prestasi. Beberapa produk yang tidak diproduksi oleh UD SBY orporation antara lain : scallop, salmon roll, tuna roll, udang roti dan bakwan. Adanya perusahaan sejenis dapat menjadi ancaman perusahaan yang cukup kuat karena bisa saja peluang pasar yang masih terbuka luas diambil seluruhnya oleh perusahaan pesaing.

\section{Ancaman Masuknya Produk Pengganti}

Suatu barang yang memiliki barang substitusi dalam jumlah yang banyak akan memiliki permintaan yang elastis, ini artinya jika harga dinaikkan oleh perusahaan, maka permintaan terhadap produk tersebut akan menurun. Hal ini terjadi karena konsumen akan beralih membeli barang substitusinya. Adanya produk substitusi dalam jumlah banyak akan membatasi keleluasaan perusahaan dalam industri untuk menentukan harga jual produk.

Produk substitusi dari produk olahan ikan yaitu seperti bakso daging, nugget ayam, sosis ayam dan daging, ekado ayam ataupun produk olahan ikan lain yang berbeda dengan UD SBY Corporation. Produk substitusi tersebut sudah cukup terkenal di kalangan masyarakat sehingga merupakan ancaman bagi perusahaan.

\section{Kekuatan Tawar-menawar Pemasok}

Analisis kekuatan tawar-menawar pemasok akan memperlihatkan sejauh mana pemasok berpengaruh dalam suatu industri untuk mengatur harga ataupun kualitas produk. Di UD SBY Corporation, bahan utama yang digunakan adalah ikan dan udang. Bahan baku tersebut didapatkan dari tujuh pedagang langganan. Seluruh pemasok berasal dari TPI Brondong dan TPI Paciran. Hal ini dilakukan agar perusahaan memiliki 
beberapa alternatif pembelian bahan baku, sehingga ketika harga ataupun kualitas di pemasok yang satu kurang sesuai maka dapat menggunakan pemasok yang lain. Namun ternyata dengan jumlah pemasok tersebut tetap saja ketika musim paceklik ikan sulit didapatkan. Sebenarnya dengan potensi perikanan Indonesia, perusahaan dapat menggunakan pemasok ikan di seluruh Indonesia, sehingga pengadaan bahan baku dapat terpenuhi meskipun musim paceklik datang.

Dari penjabaran tersebut dapat dilihat bahwa tawar-menawar pemasok tergolong rendah dan tidak terlalu mengancam keberlangsungan usaha. Hal ini terjadi jika perusahaan dapat menjalin hubungan baik dengan para pemasok yang cukup tersedia di beberapa daerah penghasil ikan di Indonesia.

\section{Kekuatan Tawar-menawar Konsumen}

Usaha pengolahan ikan terdapat di berbagai tempat, sehingga pelaku usaha harus mampu bersaing dalam mempertahankan konsumen. Konsumen produk olahan ikan memiliki posisi tawar menawar yang kuat, karena mereka dapat berpindah ke perusahaan lain yang menawarkan produk yang lebih baik dan harga yang sesuai dengan keinginan konsumen. Namun harga produk yang dijual oleh UD SBY Corporation ini bukan merupakan faktor pindahnya konsumen dikarenakan harga produk sejenis antara perusahaan yang satu dengan yang lainnya tidak berbeda. Sehingga dapat dikatakan bahwa kekuatan konsumen tidak terlalu mengancam keberadaan perusahaan.

\section{Analisis Lingkungan Internal}

Analisis lingkugan internal dilakukan untuk mengetahui faktor-faktor yang menjadi kekuatan dan kelemahan perusahaan. Analisis lingkungan internal dilakukan melalui pendekatan analisis rantai nilai.

\section{Analisis Rantai Nilai \\ Kegiatan Utama}

Merupakan aktivitas-aktivitas yang melibatkan diri dalam penciptaan fisik produk atau jasa, penjualan dan pengirimannya kepada pembeli, serta aktivitas purna jual.

1. Logistik ke Dalam (Inbound Logistic)

Kegiatan logistik ke dalam yang paling bermasalah adalah pengadaan bahan baku yang masih lemah. Hal ini biasa terjadi ketika musim paceklik ikan.

\section{Operasi}

Dalam menjalankan produksi, perusahaan telah menjalankan prosedur berdasarkan standar HACCP (Hazard Analysis dan Critical Control Points). Peraturan tersebut dibuat untuk menjaga kehigienisan produk, sehingga tidak terkontaminasi oleh apapun.

\section{Logistik ke Luar (Outbound Logistic)}

Logistik ke luar perusahaan meliputi penanganan produk jadi. Pengemasan, pelabelan nama dan tanggal kadaluarsa produk dilakukan dengan baik. Produk yang telah dikemas langsung dikirim ke pelanggan dan ada juga yang disimpan di ruang penyimpanan.

4. Pemasaran dan Penjualan

Pemasaran dilakukan melalui agen-agen dibeberapa wilayah seperti Surabaya, Gresik, Jombang, Kediri, dan sekitarnya. Penjualan produk olahan selain bakso dilakukan di Pasar Ikan Higienis, sedangkan untuk olahan bakso dilakukan di pabrik sekaligus kantor UD SBY Corporation. Selain ke agen-agen penjualan bakso, dilakukan ke para pedagang keliling baik pedagang binaan perusahaan ataupun pedagang keliling dengan modal sendiri.

\section{Formulasi Strategi}

Identifikasi Faktor Peluang dan Ancaman

Peluang merupakan sesuatu yang dapat diambil atau dimanfaatkan oleh perusahaan dengan menggunakan kekuatan yang dimiliki. Ancaman adalah sesuatu yang dapat mengancam berjalannya suatu usaha, oleh sebab itu perusahaan harus mencoba meminimalkan atau menghindari ancaman tersebut.

Adapun faktor lingkungan eksternal yang menjadi peluang, antara lain:

1. Trend konsumsi ikan semakin meningkat

Terjadinya peningkatan konsumsi ikan nasional dapat dijadikan peluang usaha. Hal ini memperlihatkan bahwa setiap tahunnya semakin banyak masyarakat yang mengkonsumsi ikan. Peningkatan konsumsi ikan didasari dengan meningkatnya jumlah penduduk Indonesia yang hingga tahun 2010 mencapai 237,6 juta orang. Selain itu berdasarkan hasil Susenas Panel Maret (2009), terlihat bahwa pengeluaran konsumsi ikan rata-rata satu bulan per kapita mengalami peningkatan pada tahun 2008 yaitu $\mathrm{Rp} 15.315$ menjadi $\mathrm{Rp} 18.454$ pada tahun 2009. Tingkat konsumsi ikan cenderung meningkat, namun seperti diketahui tingkat konsumsi ikan nasional masih tergolong rendah. Oleh karena itu perusahaan masih dapat memasarkan produk olahan ikan untuk meningkatkan konsumsi ikan nasional.

\section{Adanya program GEMARIKAN}

GEMARIKAN merupakan program yang diupayakan oleh Kementerian 
Kelautan dan Perikanan untuk mengkampanyekan pentingnya mengkonsumsi ikan kepada masyarakat sehingga masyarakat lebih paham terhadap kesehatan mereka. Adanya program tersebut secara tidak langsung menguntungkan perusahaan dan dapat dijadikan sebagai peluang, karena dengan program tersebut masyarakat mengetahui manfaat mengkonsumsi ikan dan akan lebih banyak mengkonsumsi ikan dalam bentuk apapun.

3. Adanya program pelatihan pengolahan produk hasil perikanan dari Dinas Perikanan Kabupaten Lamongan, Provinsi Jawa Timur dan Kementerian Kelautan dan Perikanan.

Program tersebut dapat memperkaya pengetahuan dan keterampilan pelaku usaha dalam hal pengolahan ikan, dengan adanya pelatihan perusahaan dapat lebih termotivasi untuk melakukan perbaikan kualitas produk sehingga produk dapat bersaing dengan produk pesaingnya.

4. Perkembangan teknologi informasi, produksi dan pemasaran

Perkembangan teknologi dapat dijadikan peluang untuk mendapatkan informasi yang mendukung keberlangsungan perusahaan. Selain itu perkembangan teknologi produksi dan pemasaran menjadikan perusahaan lebih efektif dan efisien dalam melakukan kegiatan produksi serta memudahkan dalam memasarkan produk tanpa batasan waktu ataupun tempat tujuan.

5. Adanya kesempatan UMKM mendapatkan bantuan baik material maupun non material dari pihak Dinas Perikanan Kabupaten Gresik, Provinsi Jawa Timur dan dari Perbankan

Bantuan dalam bentuk material dan non material dari pemerintah dan Perbankan dapat dijadikan peluang karena dengan adanya program tersebut perusahaan dimudahkan dalam hal modal ataupun pengadaan peralatan usaha. Bantuan tersebut didapatkan oleh perusahaan dengan memenangkan perlombaan ataupun mengajukan proposal usaha.

\section{Peningkatan PDRB per Kapita}

Adanya peningkatan PDRB Per Kapita terjadi pada daerah tujuan pemasaran produk UD SBY Corporation yaitu provinsi DKI Jakarta, Jawa Barat, dan Banten. Peningkatan ini mengindikasikan bahwa perekonomian daerah tersebut semakin baik. Ketika ekonomi daerah semakin baik maka daya beli masyarakat daerah tersebut meningkat, ketika kesejahteraan meningkat maka masyarakat akan mementingkan kesehatan dan akan mengonsumsi makanan yang sehat.
7. Pemasok ikan ada dalam jumlah banyak

Terdapat beberapa pelabuhan yang dibagi menjadi empat yaitu 1) Pelabuhan Perikanan Samudera (PPS), 2) Pelabuhan Perikanan Nusantara (PPN), 3) Pelabuhan Perikanan Pantai (PPP), dan 4) Pangkalan Pendaratan Ikan (PPI). Adanya pelabuhan perikanan yang tersebar di Indonesia secara langsung memperlihatkan bahwa terdapat banyak pemasok ikan di Indonesia.

Adapun faktor eksternal yang menjadi ancaman perusahaan, antara lain:

1. Barrier to entry usaha pengolahan ikan rendah

Setiap tahunnya pasti ada penambahan jumlah perusahaan pengolahan ikan, dan penambahan tersebut tentunya akan meningkatkan persaingan. Pengusaha yang membuat usaha pengolahan ikan tidak harus dalam skala besar sehingga siapapun dapat masuk dalam suatu industri.

2. Pesaing dengan perusahaan sejenis

Ancaman lain yang dirasakan perusahaan adalah adanya perusahaan yang sejenis tentunya produk yang dihasilkan sama dan segmentasi yang sama pula, oleh karena itu perusahaan harus mampu mengantisipasi dan membuat strategi agar usahanya dapat bertahan.

3. Persaingan dengan produk substitusi

Produk olahan ikan yang dihasilkan terbilang baru jika dibandingkan dengan produk subtitusi, seperti bakso sapi, nugget ayam dan produk lainnya, sehingga perusahaan harus memiliki cara untuk dapat bertahan dalam industri.

4. Tingkat inflasi cenderung meningkat

Adanya perubahan tingkat inflasi berdampak pada keuntungan yang diterima perusahaan. Dalam hal ini perusahaan tidak dapat menaikkan harga demi keuntungan karena harga produk bersaing dengan para pesaingnya. Selain itu tingkat inflasi juga mempengaruhi prioritas pemilihan barang atau jasa yang akan dikonsumsi oleh masyarakat. Ketika inflasi meningkat maka masyarakat cenderung mengkonsumsi makanan pokok.

\section{Identifikasi Faktor Kekuatan dan Kelemahan}

Adapun faktor internal yang menjadi kekuatan yang dimiliki UD SBY Corporation, antara lain:

\section{Lokasi perusahaan strategis}

Lokasi perusahaan baik kantor ataupun pabrik dekat dengan jalan utama sehingga mudah dijangkau oleh pemasok ataupun konsumen yang ingin membeli produk dan ingin melihat proses produksi.

2. Memiliki prestasi dan penghargaan 
Prestasi dan penghargaan yang diraih perusahaan cukup banyak, antara lain: menjadi terbaik satu dalam hal verifikasi UMKM pengolahan hasil perikanan tingkat provinsi pada tahun 2009 dari Dinas Perikanan dan Kelautan Provinsi Jawa Timur, menjadi juara satu penghargaan Adibakti Mina Bahari bidang pengolahan dan pemasaran hasil perikanan tingkat nasional tahun 2008, dan mendapatkan beberapa plakat sebagai ucapan terima kasih dari kunjungan Dinas Provinsi Riau, Dinas Provinsi Sumatera Barat, dan studi banding dari penyuluh perikanan Kabupaten Bandung. Kekuatan tersebut tentunya sangat bermanfaat apabila digunakan untuk memajukan perusahaan, karena prestasi tersebut dapat dijadikan gambaran bahwa perusahaan merupakan perusahaan yang kompeten dibidangnya.

3. Perusahaan telah menjalankan kegiatan produksi sesuai HACCP

Penerapan kegiatan produksi yang telah sesuai HACCP membuat perusahaan lebih mudah dipercaya oleh pihak eksternal dalam hal kualitas produk.

Adapun faktor internal yang menjadi kelemahan perusahaan, antara lain:

1. Pemilik tidak hanya fokus pasa satu usaha

Pemilik perusahaan tidak hanya menjalankan usaha pengolahan tetapi juga menangani proyek lain, sehingga waktu, uang, tenaga, dan pikiran terpecah. Setiap menjalankan usaha tentu perusahaan akan menghadapi permasalahan, dikhawatirkan pemilik tidak dapat fokus menyelesaikan masalah yang timbul. Hal ini menjadi kelemahan sebab pemilik memiliki peranan yang besar dalam kegiatan usaha, sehingga keberadaan pemilik secara utuh sangat penting bagi sebuah perusahaan.

2. Segala keputusan kegiatan usaha masih bergantung kepada pemilik perusahaan

Segala kegiatan perusahaan masih bergantung kepada pemilik meskipun telah ada pembagian kepala bagian. Hal ini menjadi kelemahan karena sistem organisasi tidak berjalan dengan baik dan hal tersebut dapat menghambat berkembangnya suatu usaha meskipun beberapa karyawan mampu memberi masukan untuk perusahaan karena telah memiliki pengalaman dalam usaha pengolahan tersebut.

3. Tidak adanya divisi pemasaran secara khusus

Kegiatan pemasaran yang baik akan menjadikan perusahaan berkembang dan produk tersebar luas dipasaran sehingga penjualan perusahaanpun akan meningkat. Namun pemasaran perusahaan ini masih dilakukan oleh pemilik saja dan tidak ada divisi khusus untuk kegiatan pemasaran.

4. Administrasi dan keuangan perusahaan belum rapi

Belum adanya rekening khusus untuk pengolahan ikan, sehingga uang yang masuk ataupun keluar tidak dapat termonitor secara teratur. Pendapatan perusahaan masuk ke rekening para kepala bagian, sehingga dikhawatirkan perusahaan tidak dapat secara langsung melihat jumlah uang perusahaan. Selain itu perusahaan telah membuat laporan keuangan, namun masih bersifat sederhana serta pencatatan dalam bentuk harian yang masih berupa lembaran kertas.

5. Modal usaha terbatas

Sejak awal didirikan, modal yang digunakan perusahaan merupakan modal pribadi pemilik. Keterbatasan modal ini dapat menjadi hambatan berkembangnya suatu usaha.

6. Ketidakmampuan perusahaan mendapatkan bahan baku ikan

Seperti yang telah dijelaskan, perusahaan mengalami kesulitan dalam pengadaan bahan baku ikan khususnya pada musim paceklik, sehingga ketersediaan bahan baku tersebut menjadikan perusahaan mengalami masalah dalam kegiatan produksinya.

\section{Tahap Pencocokan Matrik SWOT Strategi SO}

a. Memperluas jaringan distribusi

Lokasi yang strategis dengan akses ke jalan utama serta prestasi dan penghargaan menjadikan perusahaan lebih mudah menyakinkan agen baru untuk memasarkan produk olahan. Hal ini dapat dilakukan perusahaan dengan peluang pasar masih terbuka luas untuk pengolahan ikan yang terlihat dari meningkatnya trend konsumsi ikan. Selain itu adanya peluang teknologi yang berkembang terutama teknologi pemasaran menjadikan perusahaan mudah melakukan pemasaran ke beberapa daerah.

b. Meningkatkan jumlah penjualan produk perusahaan

Adanya peningkatan trend konsumsi ikan masyarakat yang mengartikan bahwa semakin banyak masyarakat yang menyukai ikan sehingga usaha ikan konsumsi memiliki prospek yang cukup cerah. Selain itu peluang lain yang dapat dimanfaatkan yaitu adanya program GEMARIKAN yang diadakan oleh Kementerian, Kelautan dan Perikanan hingga tingkat kabupaten membuat masyarakat paham akan pentingnya mengkonsumsi ikan, sehingga pemerintah secara tidak langsung mempromosikan ikan ke masyarakat luas, dan ketika masyarakat luas memahami 
pentingnya ikan maka mereka akan mengonsumsi ikan lebih banyak lagi.

c. Melakukan diversifikasi produk yang memanfaatkan limbah perusahaan

Perusahaan telah berhasil mendapatkan prestasi dan penghargaan yang mengartikan bahwa kualitas produk terjamin. Oleh karena itu perusahaan dirasa mampu melakukan diversifikasi produk dengan menggunakan limbah perusahaan sehingga dapat memberikan nilai tambah bagi limbah tersebut. Dalam pelaksanaannya perusahaan dapat menggunakan teknologi tepat guna ataupun mengikuti program pengolahan ikan sehingga produk yang di usulkan mendapatkan tanggapan dan hasil yang maksimal.

\section{Strategi WO}

a. Memperbaiki sistem administrasi dan keuangan perusahaan

Sistem keuangan perusahaan dapat dikatakan belum teratur. Pencatatanpun masih sering dilakukan secara manual. Oleh karena itu membuat rekening khusus produk olahan ikan dirasa perlu agar uang perusahaan dapat diketahui dengan jelas dan menata ulang sistem keuangan perusahaan dengan menggunakan laptop atau komputer setiap saat sehingga keuangan perusahaan mudah untuk dikontrol. Tentunya hal ini dapat dilakukan dengan menggunakan perkembangan teknologi yang ada.

\section{b. Mencari tambahan modal}

UD SBY Corporation tergolong usaha kecil yang masih lemah dalam hal permodalan. Hal ini disebabkan karena perusahaan hanya mengandalkan modal pribadi pemilik yang tentunya terbatas. Oleh karena itu sebaiknya perusahaan melakukan peminjaman untuk penambahan modal usaha dalam waktu dekat dan untuk jangka panjang perusahaan dapat mencari investor sehingga usaha dapat berjalan dengan lancar tanpa terkendala modal. Hal ini didukung dengan adanya program pemerintah yang memberikan bantuan modal untuk UMKM.

c. Menjalin kemitraan dengan pemasok yang ada di beberapa daerah di Indonesia

Jika dilihat peluang pemasok yang cukup banyak, maka perusahaan seharusnya mampu melakukan penyelesaian terhadap masalah tersebut dengan menjalin kemitraan dengan pemasok yang ada. Perusahaan dapat menetapkan harga sedikit tinggi, sehingga pemasok akan merasa senang dan lebih diuntungkan dengan adanya kerjasama tersebut.

\section{Strategi ST}

a. Melakukan inovasi produk olahan
Salah satu strategi untuk meningkatkan penjualan yaitu dengan membuat sesuatu yang berbeda terhadap produk. Hal ini dilakukan agar konsumen merasakan sesuatu yang baru sehingga tidak bosan terhadap tampilan produk. Selain itu perusahaan juga dapat membuat produk baru yang sesuai dengan keinginan konsumen. Hal ini tentu dapat dilakukan karena perusahaan memiliki prestasi sehingga produk yang dihasilkan seharusnya berkualitas baik.

b. Memelihara serta meningkatkan kualitas produk

Pemeliharaan dan peningkatan kualitas produk tentunya membutuhkan kekonsistenan dalam proses mengolahannya. Perusahaan harus tetap melakukan standar produksi sehingga hasil produk memang benar-benar berkualitas. Strategi ini dilakukan untuk mengurangi ancaman dari perusahaan sejenis dengan produk yang sama, serta adanya produk substitusi yang telah lebih dulu dikenal masyarakat.

\section{Strategi WT}

Restrukturisasi organisasi serta memperbaiki sistem manajemen perusahaan

Jika perusahaan ingin meningkatkan omzet penjualan, maka salah satu cara yang dapat dilakukan yaitu dengan menambah tenaga kerja untuk pemasaran. Strategi ini perlu dilakukan agar pemilik tidak kesulitan memasarkan produk sekaligus mengontrol perusahaan, sehingga dengan penambahan tenaga kerja untuk pemasaran dapat ditangani oleh bagian pemasaran dan tidak lagi menunggu keputusan dari pemilik. Selain itu sebaiknya pemilik menyusun job description yang jelas sehingga tidak ada tumpang tindih dalam pekerjaan.

\section{KESIMPULAN DAN SARAN \\ Kesimpulan}

Berdasarkan hasil penelitian yang dilakukan pada usaha pengolahan ikan UD SBY Corporation, didapatkan kesimpulan sebagai berikut:

1. Berdasarkan analisis lingkungan eksternal perusahaan didapatkan faktor peluang yang dihadapi perusahaan antara lain: (1) Trend konsumsi ikan semakin meningkat, (2) Adanya program, GEMARIKAN, (3) Adanya program pelatihan pengolahan produk hasil perikanan dari Dina Perikanan Kabupaten Gresik, Provinsi Jawa Timur. (4) Perkembangan teknologi informasi, produksi dan pemasaran, (5) Adanya kesempatan UMKM mendapatkan bantuan baik material maupun non material baik dari pihak Dinas Perikanan dan dari perbankan, (6) Peningkatan 
PDRB perkapita dan (7) Pemasok ikan ada dalam jumlah yang banyak. Sedangkan faktor-faktor eksternal yang menjadi ancaman antara lain: (1) Barrier to entry usaha pengolahan ikan rendah, (2) Persaingan dengan perusahaan sejenis, (3) Persaingan dengan produk substitusi dan (4) Tingkat inflasi yang cenderung meningkat.

2. Berdasarkan analisis lingkungan internal perusahaan didapatkan kekuatan perusahaan antara lain: (1) Lokasi perusahaan strategi, (2) Memiliki prestasi dan penghargaan, (3) Perusahaan telah menjalankan kegiatan produksi berdasarkan HACCP. Sedangkan kelemahan perusahaan antara lain: (1) Pemilik tidak hanya fokus menjalankan pada satu usaha yaitu usaha pengolahan ikan, (2) segala keputusan kegiatan usaha masih bergantung pada pemilik perusahaan, (3) tidak adanya divisi pemasaran secara khusus, pesamaran dilakukan oleh pemilik, (4) Administrasi dan keuangan perusahaan belum rapi, (5) Modal usaha terbatas, dan (6) Ketidakmampuan perusahaan mendapatkan bahan baku ikan.

\section{Saran}

Saran yang dapat diberikan untuk UD SBY Corporation berdasarkan hasil penelitian, sebagai berikut:

1. Pelaksanaan program-program hasil dari arsitektur strategi sebaiknya menjadi pertimbangan untuk mencapai sasaran tiga tahun ke depan, dan untuk menjalankannya dibutuhkan kekonsistenan para pelaku usaha.

2. Sebaiknya dilakukan penelitian lebih lanjut mengenai faktor-faktor apa yang mempengaruhi minat beli ulang produkproduk olahan ikan UD SBY Corporation

\section{DAFTAR PUSTAKA}

Badan Pusat Statistik. 2009. Pengeluaran Untuk Konsumsi Penduduk Indonesia Per Provinsi. Berdasarkan hasil Susenas Panel Maret 2009.

Badan Pusat Statistik. 2010. Tren Jumlah Penduduk Indonesia. Survei tahun 2010.

David, FR. 2009. Manajemen Strategis Konsep. Salemba Empat. Jakarta.

Irianto, HE., Soesilo, I. 2007. Teknologi Pendukung Pengujian dan Jaminan Mutu Dukungan Teknologi Penyediaan Produk Perikanan. Seminar Nasional
Hari Pangan Sedunia 2007. Kampus Penelitian Pertanian Cimanggu. Bogor.

Widiarti, A, dkk. 2010. Warta Pasar Ikan. Edisi Januari 2010, volume 77. Direktorat Pemasaran Dalam Negeri, Direktorat Jenderal Pengolahan dan Pemasaran Hasil Perikanan 